\title{
КОМПЛЕКСНІСТЬ ЯК ПРОВІДНИЙ ПРИНЦИП ОРГАНІЗАЦІЇ І ДІЯЛЬНОСТІ ШКІЛЬНОЇ ОСВІТИ (1920-і роки)
}

Розвиток радянської школи у 1920-х роках викликає у дослідників великий інтерес в останні 20 років, коли наново переглядається і переосмислюється вся історія вітчизняної школи.

Підвищена увага до тї діяльності зумовлена також процесами, які нині відбуваються в освітній галузі України, і зокрема висуненні ідей і перших кроках впровадження «Нової української школи» (НУШ). Знайомлячись 3 документами про НУШ, знаходимо перегук і співпадіння концептуальних ідей між педагогікою і практикою 1920-х років і сучасними кроками у розбудові освітнього простору, що особливо актуалізує дослідження явищ, які відбувалися в далекі роки. 3 усього розмаїття процесів, що здійснювалися тоді в українській школі, нас передовсім цікавить комплексність як багатовекторний чинник розвитку середньої освіти у зазначений період.

Проте маємо лише декілька праць, які цілісно аналізують освітній процес цього періоду, де серед іншого розглядається і питання комплексності [17; 3; 2]. В цілому ж цей період - 1920-х початок $1930-x$ років у сучасному дослідницькому полі представлений досить великою кількістю кандидатських дисертацій (більше 40), але їхня присутність не відчувається і не впливає на сутність i глибину дослідженості педагогічних і освітніх процесів, що відбувалися у ці роки. До того ж вони присвячені окремим напрямам розвитку педагогічної науки і практики, і серед них: державній політиці щодо дитинства і зокрема щодо соціально вразливих дітей, трудовим процесам у школі, викладанню окремих дисциплін тощо. Питання комплексності, комплексного навчання ці праці не розглядали або ж розглядали побіжно. Серед публікацій 3 цієї теми назвімо передусім розділ за моїм авторством «Комплексне навчання в школах України» у навчальному посібнику «Нариси з історії українського шкільництва» (1905-1933), що вийшов друком ще у 1996 році і став однією з перших розвідок цього феномену [28]. Серед публікацій останніх років відзначаємо монографію Т. Янченко «Педологія в Україні та зарубіжжі: теорія і практика», в якій розкривається вплив педології на організацію та зміст шкільної освіти [35], а також статті
I. Большакової [3] та Л. Ковальчук [10], предметом дослідження яких виступає міжпредметна інтеграція (І. Большакова) та результативність навчального процесу крізь призму педології (Л. Ковальчук).

Така кількість розвідок недостатня, адже питання комплексності й комплексного підходу - це центральне питання діяльності школи і педагогіки 1920-х років. Вона була стрижневою, постійно обговорюваною на шпальтах радянських педагогічних періодичних видань, таких як «Шлях освіти», «Радянська освіта», «Просвещение на Донбасе» та інших. Особливу увагу цій темі приділяла газета «Народний учитель» (1925-1930), у кожному номері якої була представлена та чи інша точка зору; виходили також невеликі тематичні книжечки, присвячені цій проблемі. Уся ця сукупність джерел свідчить, що питання комплексності в освіті було одним з найбільш гострих, дебатованих і контроверсійних.

Що ж таке комплексність у освіті стосовно школи і педагогіки 1920-х років? Хоча науковці, як правило, співвідносять їі передовсім з навчальним процесом, це явище значно ширше й багатоаспектніше, адже за їі допомогою радянська влада планувала змінити всю освіту. Ось як про це говорив у 1923 році нарком освіти РСФРР А. Луначарський: «Це (нова комплексна програма - О.С.) щось в повному сенсі слова дійсно визначне... блискуча схема... Це цілковитий переворот у справі народної освіти. Це річ, яка, коли ми зможемо їі розвинути, матиме всесвітне значіння» $[14$, с. 55].

3 установленням більшовистської влади в Росії перед новою школою було поставлено завдання - вивчення життя в усіх його кардинальних змінах і проявах з метою перетворення і дитини/людини, і дійсності на засадах «революційного» матеріалізму і марксизму. Шляхом досягнення цих цілей в освіті була обрана комплексність, як інструмент для розуміння докорінних змін та перетворень. Вона мала спиратися на інтегровану науку про дитину, якою послуговувалася педагогіка i освіта у своїх науковопрактичних перспективах і діях і яка в Радянському Союзі розвивалась як марксистська педоло- 
гія. Як зазначав Л. Виготський, педологія керувалася «діалектико-матеріалістичним розумінням свого предмета», тобто ідеєю цілісності (розкриття зв'язків, вивчення нових якостей, своєрідних особливостей онтогенезу) та ідеєю розвитку як пояснювального принципу, тобто «розвиток як прямий об'єкт дослідження» [5]. До неї додавалися такі нові науки як психотехніка, наукова організація праці (НОП).

За такого підходу комплексність від самого початку розглядалася і як принцип організації усього шкільного життя, і як спосіб організації навчання дітей у школі, i як форма побудови змісту освіти, і як головна структурна складова навчального процесу, і як підхід до організації навчально-виховного середовища.

В навчальному процесі під комплексним методом розумівся «метод злитого єдиного вивчення цілого комплексу явищ: трудових, природних і суспільних. Організаційно таке вивчення, - писав відомий тогочасний російський педагог М. Пістрак, - оформлюється у вигляді вивчення не звичайних, ізольованих один від одного шкільних предметів, а «центральних» тем, розробка яких дає учням усі потрібні їм у цей момент знання і навички. Центром вивчення стає комплексна («центральна») тема; всі необхідні знання і навички здобуваються в ході вивчення цієї комплексної теми [22, с. 119]. Тема, обрана центральною, розподілялася за 3-ма колонками: «природа», «праця», «суспільство», основною 3 них вважалася «праця». Комплексність, трудовий принцип, опертя на «революційні» суспільні зміни, які пробуджували активність, самодіяльність, дослідництво дітей, стали основою, на якій вибудовувалася нова школа.

Перш ніж розглянути перебіг розробки і застосування комплексної системи в СРСР, зупинимося на витоках цих ідей, які народилися значно раніше у зарубіжній і вітчизняній педагогічній думці. Про об'єднання навчання навколо цікавих для дитини тем говорив ще Ж.-Ж. Руссо у XVII ст.; I. Гербарт на початку XVIII ст. висував ідею зв'язку предметів навчання на основі викладання географії як предмета, що охоплює усі наукові галузі; німецькі педагоги Т. Ціллер та В. Рейн в кінці XIX ст. пропонували організацію освіти через загальношкільне планування у вигляді концентрування навколо певних тем.

Особливого розвитку ідеї комплексування навчального матеріалу отримали у першій третині XXст. у реформаторській педагогіці, яка пов'язувала їх з розвитком активності дитини, її пізнавальної, ігрової, трудової діяльності. Особливу увагу цим питанням приділяли Дж. Дьюї (активність, діяльнісний і проектний підходи, трудовий принцип), О. Декролі («центри інтересів» як засіб розвитку потребнісної сфери дити- ни), Г. Кершенштайнер (трудовий принцип) тощо. Широке застосування на початку XX століття отримав тематичний i інтегрований підхід до навчання у Німеччині, Швейцарії, Бельгіï, США в процесі організації дошкільного виховання та початкової школи як: концентрація навчального матеріалу навколо життєвих (трудових, побутових) явищ та відповідних тем; кореляція (на основі внутрішніх зв'язків всередині матеріалу); асоціація (об'єднання випадкових тем) [28, с. $176-$ 178].

У вітчизняній педагогіці ці процеси започаткував К. Ушинський, запропонувавши об'єднувальні теми навколо навчального предмета «Родная речь», взяті із життя дитини, ії найближчого оточення. Ідеї, близькі до комплексності, розвивалися методистом М. Бунаковим («Живое слово», «Книжка-первинка»), а в теоретичному плані - відомим педагогом П. Каптерєвим в праці «Дидактические очерки. Теория образования» (1915).

Як показує цей короткий екскурс в історію, ідеї комплексності вже були відомі вітчизняній педагогіці, особливо ії реформаторському крилу, сприймалися практиками, але не знаходилися в центрі уваги офіційної педагогіки, були швидше винятком, ніж правилом.

Розглядаючи власне історію комплексності в УСРР, передусім проведемо аналогії з розвитком комплексування в РСФРР, оскільки звідтіля українська педагогіка і практика періоду 1920-х років запозичувала ідеї «революційної» педагогіки.

У Росії розвиток шкільних навчальних програм у вигляді комплексів пройшов декілька етапів. Їх визначив у 1934 р. М. Пістрак і поділив їх так: перший: 1918-1922 рр. - створення засад побудови єдиної трудової радянської школи згідно «Декларація про єдину трудову школу» (1918), де головною метою висувалася активна, творча самодіяльна особистість, а трудовий принцип пронизував усю іiі діяльність. Навчальна програма уявлялася як великий «комплекс» «трудове знайомство з оточуючою дитину природою і суспільним середовищем». Автор зазначає, що Декларація і програми будувалися на засвоєнні ідей «передових представників буржуазної педагогіки, (в першу чергу - 3 Дьюї) [22, c. 115-117].

Другий етап - 1922-1927 рр. - оформлення програм, які в основу навчального плану поклали «схеми Гусу»1, що складалися 3 трьох колонок: «природа», «праця», «суспільство». Згідно цієї схеми у початковій школі відмінялися предметна

1 ГУС (Государственный ученый совет при Наркомпросе РСФСР). Оскільки у історико-педагогічній літературі закріпилося скорочене написання цього органу саме російською мовою, ми застосовуватимемо саме його в подальшому нашому викладі. 
система, розподіл годин, а навчання будувалося на основі комплексної теми. Формальні знання, вміння і навички особливо 3 математики, мови здобувалися «попутно, по ходу вивчення комплексу. Заперечувалася необхідність як виділення особливого часу для вправляння у навичках, так і необхідність підбору спеціального матеріалу для вправ» [22, с. 119-120].

Програми ГУСу в ці роки містили різні рівні комплексування - амальгамування (повної інтеграції в початковій школі), комбінування (інтеграції на рівні розподілу ряду предметів) і координаціï (тематизації, тематичного підходу), допускалося вивчення окремих предметів у п'ятихсьомих класах семирічки. Вони носили орієнтовний характер, мали стати орієнтиром для розробки місцевих програм.

Третій етап розвитку програм ГУСу - 19271929 рр. - переробка програм попереднього періоду, усунення недоліків, які проявилися в процесі роботи за новими схемами.

Наступний, четвертий етап, за М. Пістраком, це 1929-1931 рр., коли отримали своє застосування комплексно-проектна система та метод проектів. В ці роки програма ГУСу як система організації і діяльності школи, зазнавала все більше критики як серед ії прихильників, так і супротивників, незважаючи на ії постійне корегування. Вона все більше розходилася із цілями і завданнями радянської політики й економіки. На початку 1931 р. були сформовані нові комплекснопроектні програми для початкової школи, які мали наблизити школу до завдань соціалістичної реконструкції країни, але вони, як відомо, проіснували дуже недовго.

За схожою схемою, але з суттєвими відмінностями, розвивалася школа і в УСРР. Перш за все підкреслимо, що комплексність почала масово проникати в школи в Україну пізніше, тобто в 1919/1920 роках, коли на деяких українських територіях почала встановлюватися радянська влада. За часів же Української революції 19171921 рр. освітяни більше опікувалися насиченням навчальних предметів українознавчим і народознавчим змістом, запровадженням рідномовної (україномовної) освіти, демократизацією організації й змісту педагогічного процесу в школах і вищих навчальних закладах. Кардинальних перетворень в структуруванні змісту освіти та методиці викладання предметів у ці роки не спостерігалося.

Значні зрушення починають відбуватися 3 1920 року, з початком утвердження радянської влади, яка поставила за мету здійснити радикальні зміни не лише у політиці, економіці, а й у культурі, освіті. В цьому ж році була розроблена і затверджена «Декларація Наркомосу УСРР про соціальне виховання дітей», була схвалена схема розвитку народної освіти, які, як нам добре відомо, суттєво відрізнялися від аналогічних російських, але все ж нарком освіти УСРР Г. Гринько на одній із партійних нарад підкреслив: «Жодного кроку не повинно робити без уважного вивчення й обліку досвіду Радянської Росії» [16, с. 106].

Аналітичні статті, присвячені комплексному підходу в організації навчання в Україні, з'явилися ще у 1920-х роках. Українські автори (Т. Гарбуз, І. Лень, П. Мостовий, В. Павловський), які їх розглядали, поділили цей процес на певні етапи ще тоді, хоча час його застосування був незначний. У нашому викладі будемо аналізувати їхні міркування, але попередньо зробимо декілька зауважень.

В 1920-х роках організація навчального процесу і структура навчального року регламентувалася в загальних рисах - єдиного підходу, єдиних вимог до них не було: у різних регіонах (округах) УСРР встановлювалася своя структура навчального року, яка затверджувалася місцевими органами освіти. Навчальні плани називалися «табелями» і не були обов'язковими для шкіл. У всій республіці шкільний рік був поділений на такі триместри: осінньо-зимовий, зимововесняний i весняно-літній, що відповідало, на думку освітян, новій виробничо-трудовій сутності школи. Кількість днів навчання також чітко не визначалася, наприклад, у 1926/1927 навчальному році Наркомос рекомендував 224 навчальні дні. «Проте, - як зазначає сучасний дослідник, на місцях до цих рекомендацій мало хто прислуховувався. Місцеві органи освіти у переважній більшості не виконували рекомендацій стосовно початку навчального року і починали його не у вересні, а у жовтні. Подекуди навчальний рік починався лише у листопаді» [13, с. 126].

Були відмінені також уроки, класи, оцінки, переосмислювалася роль учителя в педагогічному процесі у бік іiі применшення, вторинності, зведення до консультативних і дорадчих функцій. У керуванні освітою Наркомос надав багато повноважень місцевим органам, окружкомам, які не дуже чітко уявляли шляхи досягнення мети і завдань, заявлених у «Декларації». Для надання професійності й керованості цим процесам Наркомос з 1921 і до 1928 року видавав «Порадник соціального виховання» - збірник директивних і рекомендаційних актів Наркомосу УСРР, де серед інших містилися й матеріали щодо організації навчально-виховного процесу та його перебігу, особливо в початковому концентрі школи (1-4 класи).

Виходячи 3 політичних, соціальноекономічних, педагогічних обставин, що склалися в УСРР, перший етап розробки нових програм вищезазначені автори відносять до 1921-1923 років, коли були створені перші навчальні програ- 
ми Наркомосу, оприлюднені у першому «Пораднику соціального виховання» (1921), який, не вживаючи термін «комплексність», усе ж радив організовувати навчальний процес у наступний спосіб: «1) дотик дитини і природи, 2) виробнича праця дітей, 3) навчання на основі психічної активності, 4) відпочинок дітей, гри, розваги і т.п.» [16, с. 107]. Тобто, власне про саму організацію тут не йдеться, все подано загальними фразами, у дусі «Декларації Наркомосвіти УСРР про соціальне виховання дітей» (1920), яка в цілому, крім соціальних моментів, носила яскраво виражений педоцентричний характер. На неї справили значний вплив російські керівні документи: «Декларація про єдину трудову школу» (1918), «Положення про єдину трудову школу» (1919) та «Примірні програми 1920 року» та інші. В цілому українські керівники освіти запозичували напрями і схеми діяльності прямо із російських документів, а також опосередковано - через «Порадник» 1921 р., який багато в чому слідував російським напрацюванням. Про це пишуть у своїх аналітичних розвідках дослідники комплексності кінця 1920-х - початку 1930-х років П. Мостовий, В. Павловський, праці яких ми використовуємо як джерела. Але не відкидаємо також і відкритості української педагогіки і школи до зарубіжних течій і напрямів, що активно розвивалися в той час на Заході. Наприклад, через найбільш масовий педагогічний журнал «Радянська освіта» відомий педагог Григорій Іваниця знайомив освітян 3 джерелами, у яких розкривається сутність комплексного навчання. Крім російських авторів він називає португальського педагога Антоніо Фаріа де Васконселос (концентрація матеріалу навколо вивчення природи, оточення та батьківщини), Джона Дьюї (кореляція, перенесення центру уваги на методи шкільної праці), Вільгельма Лая та Адольфа Фер'єра (комплексний підхід до побудови шкільного навчального плану) та інших [9].

Якщо відкинути ідеологічну риторику, пафосність мови щодо цілей освіти і виховання в дусі «комуністичного майбутнього», в цілому в українських документах обстоювалися ідеї про розвиток і формування дитини за біогенетичними законами, які, втім, в той час розцінювалися як марксистські. Ось як про це писав В. Павловський: «На початку революції об'єкт виховання - дитина розглядалася як біологічна істота, що іï розвиток іде за біогенетичним законом, цей закон зумовлює розуміння педагогічного процесу як поступового розгортання властивостей, що заховано в дитячій історії. Звідси нехтування програмових питань, бо таємниці дитячої природи неможливо вкладати в рямці логічно побудованих вимог дорослих, звідси широкі межі методичних засобів, бо їх не пристосуєш до своєрідних особливостей кожного дитячого організму» [20, с. 47].

Організація дитинства, і в першу чергу через заклади охорони дитинства і освіти, вибудовувалася через «вивчення дітей, вивчення усіх зовнішніх обставин життя, що оточують дітей, врахування всіх постійних і можливих випадкових факторів, що викривлюють, спотворюють це життя, i, насамкінець, постійне вивчення біологічних і соціальних законів еволюції людини, так, щоб кожної миті своєї творчої праці змогти... зрозуміти, передбачити їхні потреби, усунути всі фактори, що гальмують розвиток і розширення цих потреб і інтересів, і постійно уважно спостерігати і йти за дитячими зусиллями» [31, с. 4]. Ці слова написані М. Тарасевичем, керівником Одеського педологічного інституту, керівником науково-дослідної кафедри педагогіки, яка організувала і спрямувала усю організацію життя дитини на півдні України.

Що ж до реального стану шкільного навчання, то на цьому етапі переважно зберігалася предметна система навчання, бо через скрутні, навіть катастрофічні матеріально-економічні умови, більшість шкіл працювали або зовсім нічого не змінюючи, або за російськими планами і програмами. Водночас українські освітяни намагалися розробляти власні навчально-методичні підходи. Сучасний український дослідник цього періоду стверджує, що: «в 1919/1920 навчальному році Наркомос залучив найкращі сили вчених, організаторів освіти і педагогів для розробки нових навчальних програм для єдиних трудових шкіл. При Наркомосі була створена постійна комісія консультантів, до складу якої увійшли видатні вчені України: О. Паладін, Д. Багалій, П. Фомін та інші. В 1920 р. нові навчальні програми та плани надійшли до шкіл. Вони були розраховані на предметну систему і надавали перевагу навчанню математики та природознавства» $[13$, с. $128-129]$.

Судячи 3 відсутності згадувань про них у джерелах, вони так і залишилися проектами. Відтак, у 1920/1921 навчальному році у шкільному розкладі залишалася предметна система. яка або була продовженням старої (до 1917 р.), або періоду УНР, або ж запозиченої у РСФРР. Так, у першому концентрі вивчалися рідна мова, арифметика, краєзнавство, природознавство, географія, малювання, співи, фізкультура, ручна праця [13, с. 127].

Але у подальшому планувалося проводити навчальний процес не на предметній, а на комплексній основі, а керівництво цим процесом віддавалося на місцевий рівень. «Порадник» ще залишався директивним документом, що хоч і у загальний спосіб, але урегульовував структуру і наповнював змістом навчально-виховний процес у школі. 
У 1922 році виходить друге видання «Порадника», яке в цілому закріплює педоцентричні та біогенетичні засади розвитку освіти, але робить більший наголос на трудовому принципі. В. Павловський відзначає, що «замість школиклюбу ми знаходимо вже положення про трудову школу, а також програми 3 певних дисциплін. Зокрема чіткіше подається зміст трудового виховання у спеціальному розділі “трудознавство”. Воно складається з трьох видів: а) самообслуговування і трудових процесів, що вимагає господарство дитячої установи; б) ознайомлення дітей 3 основними галузями праці, що поширена в районі дитячої установи, в) в організації праці, що забезпечує художньо-естетичний розвиток дитини» $[21$, с. 46].

У «Пораднику» 1922 р. ще не віддавалася перевага одному чиннику розвитку дитини біологічному чи соціальному, але все виразніше звучали соціальні мотиви - все життя дитини розглядалося, як процес соціалізації, організації життя в колективі згідно з їі власною природою; значна увага приділялася і природному середовищу, краєзнавчому підходу. Цей «дуалізм між біологічним і соціальним затушковував виразність педагогічного процесу, бо невідомо було, якому з яких чинників віддати примат, звідки починати розгортання цього складного вузла», писали тогочасні дослідники [20, с. 48].

Але цей «дуалізм» був швидкоплинним вже в 1923 році було обрано соціологічний підхід, який став симетричною відповіддю на розгортання політико-ідеологічних процесів, радянізації суспільного життя. Він отримав наукову опору в рефлексологічному напрямі розвитку науки i класифікувався як соціобіологічний. Найбільш гарячим прихильником цього підходу в українській педагогіці став І. Соколянський, який зазначав у своїх тезах про біологічні та соціальні моменти диткомруху, «Що поведінка людської особистості визначається факторами двоякого роду: а) біологічними (внутрішніми), б) соціальними (зовнішніми). Перші (біологічні, внутрішні) - ускладнюють поведінку, а другі (соціальні, зовнішні) - обумовлюють поведінку. Норми поведінки і форми, що з них випливають, обумовлюються факторами соціального порядку (зовнішніми). Біологічні моменти завжди і неминуче ускладнюють в той чи інший спосіб поведінку» [25, с. 207].

Отже, перший етап може класифікуватися як період інтенсивних педагогічних шукань теоpiï ѝ методології комплексності: педоцентричний чи соціобіологічний щодо організації і підходів до навчального процесу; біогенетичний чи рефлексологічнй в якості теоретичних засад, які всі спиралися на марксистсько-партійну риторику.
В практичному плані керівні органи й пересічні освітяни перебували у перебудовчому процесі, який носив виразні риси хаосу і невпевненості, сприйняття і заперечення, руйнацією старої школи і зусиллями створити нову школу. «Порадники» цих років давали або ж такі різноманітні «поради», розлогі й багатоаспектні, що більшість учителів віддавали перевагу російським схемам ГУСу або ж традиційній урочній системі.

В таких умовах в 1924 році на IV сесії Науково-педагогічного комітету Укрголосоцвиху були ухвалені перші українські комплексні програми для школи першого концентру (1-4 класи), що започаткували новий етап в розвитку ідей комплексності в Україні, який продовжувався до 1927 р. В тому ж 1924 році вийшов «Єдиний навчально-виховний план соцвосу», який мав розгорнутий і докладний характер, у вступній частині надавав загальну характеристику навчально-виховного процесу як комплексному, в центрі якого знаходяться суспільствознавство, трудознавство і природознавство, тобто «суспільство» - «праця» - «природа» - за колонками комплексу, а також докладну «Орієнтовну комплексну програму семирічної трудової школи», яка займала сто сторінок і подавала окремо програми сільської і міської шкіл, а також містила орієнтовні програми формальних знань, до яких було віднесено українську і російську мови і літератури, а також математику і астрономію [8]. Відзначимо, що це був час певної стабілізації в економіці країни, розгортання нової економічної політики. Загальна атмосфера стала спокійнішою, сприятливішою розвитку освіти й вихованню дітей.

У загальнотеоретичному аспекті ці програми вибудовувалися на соціобіологічній поведінковій теорії, але акцент у ній було перенесено 3 дитини на колектив. Це було вичленено й артикульовано у «Пораднику» 1924 року видання. Так, В. Павловський зазначав, що «проти інших видань "Порадника", що надавали великого значіння особі дитини й будували педпроцес на педоцентризмі, до 4-го видання внесено грунтовні зміни так у загальну його частину як і в розділ про єдиний учбово-виховний план. Не особу дитини 3 iї психологічними особливостями взято тепер за основу педагогічного процесу, а дитячий колектив 3 його внутрішніми і зовнішніми взаєминами суспільного й природничого оточення, що вона в ньому перебуває... Буйний розквіт дитячого комуністичного руху, з одного боку, і славетні дослідження об'єктивної школи фізіологів щодо трактування людської поведінки 3 другого, кардинально вплинули на напрям педагогічної думки» [20, с. 47-48].

3 цього року комплексність стає «альфою і 
омегою» українських педагогічних шукань. Підкреслимо ще раз, що порадники лише радили, а остаточне рішення приймали місцеві органи освіти в залежності від умов, як педагогічних, так і соціально-економічних, демографічних. Увесь радянський період, особливо після 1920-х років, комплексний підхід, комплексність звинувачували у відсутності системності, послідовності, наступності, нехтуванні формальними знаннями, уміннями й навичками.

Аналіз літератури засвідчив, що керівники освіти й не планували, не ставили за мету такі завдання - навпаки, вони всіляко уникали, легковажили изми засадами й складовими, які уособлювали для них $i$ для держави стару школи й віджилі приниипи. Їхньою метою стали активність, діяльність, ініціативність дітей, трудовий принции, зв'язок з виробниитввом, з життям, з иоого миттєвостями, щуо проживалися дитиною, з живою реакиією на події. Краєзнавчий приниип, дослідниитво ӥ експериментування виступали провідними засадами діяльності шкоми. До изих суто педагогічних складових додавалися не менш важливі політичні.

Прикметно, що в цей період диференційовано підходили до вивчення дітей різних національностей, бо, згідно з педологічними і соціобіологічними підходами, діти різних національностей, особливо національних меншин, мали, якщо говорити сучасною мовою, різні архетипи розвитку, різні генотипи (згідно з біогенетичним законом) і різний ступінь самоусвідомлення (самоідентифікації) [4].

«В кінці 20-х років, - зазначає професор Кембріджського університету О. Еткінд, - проводиться серія педологічних експедицій у віддалені регіони країни: формується нова галузь досліджень - педологія нацменшин, точний еквівалент сучасної дитячої етнопсихології. Були проведені дослідження дітей і підлітків Бурятії, Алтаю, Узбекистану, татарських школярів Москви. Це була серйозна, але до цього часу належно не оцінена робота» [34]. Українська дитина також була суб'єктом і об'єктом вивчення цих наук.

В ці роки національний підхід відігравав велику роль і в організації дитинства, і в комплексуванні змісту освіти. Так, за національною приналежністю організовувалася навчальновиховна діяльність закладів освіти різних типів шкіл, комун, дитячих будинків, створювалися «українські», «російські», «єврейські», «польські» школи, дитячі будинки, а в межах однієї установи - відповідні колективи [32].

Всі ці процеси були новими, незвичними для учительства, і впродовж усього другого етапу спостерігаємо розгортання, переважно на шпальтах періодичних видань, гострої дискусії про те, що ж таке комплексність, комплексування, комплексний підхід. У 1996 р. ми проаналізували різні підходи українських педагогів до комплек- сності [28, с. 188-202]. Відсилаємо читачів до цього тексту, тут же коротко зазначимо, що у 1920-х роках українські дослідники розрізняли три підходи до комплексування в загальноосвітній школі: Григорія Іваниці (дидактичний), Олександра Музиченка (загальнопедагогічний) та Івана Соколянського (соціально-класовий). Окрему думку щодо комплексування мав Яків Чепіга, який, хоча і давав багато порад учителям щодо проведення занять за комплексами, загалом виступав проти всезагального застосування комплексності і відстоював трудовий метод як єдиний у здобуванні знань учнями [33].

Докорінне переформатування освітньої системи, навчального матеріалу, відмова від звичного, традиційного погляду на освітній процес, внесення до нього складових, які доти не були йому притаманні, різні погляди на комплексність, навчальну літературу, роль й значення вчителя викликали лавиноподібні процеси в педагогіці і освіті, які стосувалися не лише розуміння і застосування комплексів, а й набуття учнями знань, умінь та навичок, що залишалося болючим питанням і для керівників освіти, і вчительства.

До того ж підручників було обмаль, відчувалася гостра потреба у навчально-методичній літературі, створення якої значно відставало від продукування нових ідей². Як відзначали тогочасні дослідники, і зокрема В. Павловський, на якого ми неодноразово посилалися, «кардинальна зміна в організації педагогічного процесу за комплексної системи привела до потреби відмовитися майже від усіх підручників старого типу й спрямувала на роботу навколо утворення цілої серії робітних книжок, хрестоматій, задачників, що їх наповнено новим змістом за комплексними темами. Новий зміст освіти й нова мета його застосування природно викликали потребу в нових формах організації праці і нових методах його проведення. Краєзнавчі і виробничі екскурciï, спостереження, безпосередня праця дітей по обслуговуванню, у майстернях і особливо у сільському господарстві входили до комплексів і набули великого поширення» [21, с. 49].

3 огляду на нові мету («створення нового покоління людей комуністичного суспільства 3 психологією колективіста)» і завдання освіти (концентрація на «вузлах життя», трудовий процес, діяльність, спрямована на перетворення світу) питання нових організаційних форм і мето-

\footnotetext{
2 Наведемо, як приклад, ті, що рекомендувалися Наркомосом УСРР: Блонський П. П. Красная зорька. Первая книга для чтения в сельськой школе. Москва, 1923; Астряб О., Дога В. [та ін.]. До праці: робоча книжка для другого року навчання в сільській трудовій школі. 5-е. вид. Харків: Держ. вид-во Україниб 1926. 320 с.; Іваниця Гр., Чепіга Я., Якубовський Б. Шляхом життя. Читанка для 6-7 груп трудової школи, робфаків, шкіл для дорослих і т. ін. Київб 1925. Ч. 2.
} 
дів навчання висунулося на передній план. Тобто «що» було визначено і запропоновано в комплексах, але гостро постало питання «як», тому що навчальний процес спирався на комплекси, а не навчальні предмети. I тут знову на допомогу прийшов зарубіжний досвід, але 3 радянськими модифікаціями й інтерпретаціями.

Загальнодидактичні методи, що розвивалися і отримали в той час найбільш широке застосування: педологічні (співвідношення методів 3 відповідними віковими змінами в дитячій фізіології); психотехнічні (психофізіологічні з співвіднесенням виявлення здатності до певного типу праці); дослідницькі, які тлумачилися як провідні в організації всієї освітньої діяльності. Для цих останніх важливим було, як зазначає М. Богуславський, «зв'язок методу не лише 3 пізнавальною діяльністю 3 оволодіння змістом освіти, але і 3 дією, спрямованою на перетворення оточуючого середовища» [2, с. 219], що передбачало застосування активних форм $і$ методів навчання, які в той період почали відігравати першорядну роль. I нині, у сучасній історикопедагогічній літературі, присвяченій цьому періодові, найбільша увага приділяється саме формам і методам, а про комплекси, тобто про зміст, говориться побіжно.

Основним завданням нової школи щодо форм і методів навчання було «знесення», як висловився провідний педагог того часу С. Ананьїн, тобто відмова від лекційної системи, бо вона асоціювалася зі старою, традиційною школою. Та, мабуть, в умовах комплексної системи іï широке застосування було неможливим. Натомість почали пропагуватися, навіть насаджуватися такі методи навчання як Дальтонплан (Долтон-план), напівдальтон план, клубні заняття 3 відповідною організацією роботи: бригадно-лабораторна, проектна, ланкова системи. С. Ананьїн, розглядаючи різні форми й методи, одним з перших називає «дальтонський план» [1, с. 21].

Дальтон-план - система індивідуалізованого навчання, впроваджена в життя американським педагогом Елен Паркхерст, спирається на вільний вибір дитиною занять, довільне використання свого навчального часу і послідовності вивчення предметів. За Дальтон-планом увесь навчальний матеріал поділявся за місяцями на підряди, а ті в свою чергу - на щоденні завдання. На початку навчального року кожен учень укладав з учителем договір (контракт) про самостійне виконання певного завдання за певний час. Учні працювали в окремих предметних кабінетахлабораторіях (звідси і ще одна назва цієї форми лабораторний план).

Радянська школа сприйняла цю інновацію i намагалася пристосувати іï до свого другого концентру (5-7 кл.), але індивідуальний підхід мав бути замінений на колективний. Учителі намагалися охопити цим методом усі групи (класи) другого концентру. Найбільша кількість завдань давалася дітям на 4 тижні, попередньо проводилися загальні колективні бесіди для введення в тему, визначення методів роботи і матеріалів, літератури, висвітлення «трудових моментів». При завершенні роботи також проводилися збори, де підводилися підсумки, виокремлювалися недоліки, контролювалося виконання. Особлива увага приділялася технології обліку здійсненої праці: для цього запроваджувалися особисті картки учнів, де визначався день роботи і час, витрачений на «проробку матеріалу»; здійснену роботу вчитель засвідчував своїм підписом; застосовувалися і класні картки, де графічно відображалася кількість проробленої роботи; а також класно-предметні картки, що зберігалися в учителя і де відзначалася пророблена робота, іï характер та ступінь виконання [23].

Зазначимо, що всі новації, і серед них Дальтон-план, учительством, яке у своїй масі було консервативним, сприймалися насторожено. Аргументи проти нього були такими: «ламання шкільного життя», «учні мусять вже хоч трохи тямити працювати самотужки..., мати певний ряд уявлень 3 відповідних галузів», «дальтоновський план не витворює, не зміцнює дитячого колективного життя й не ставить цього завдання як основного, ... не вилучає педагогічного індивідуалізму», вимагає «іншого опорядження шкіл», «учительство повинно мати іншу підготовку й інші навчальні засоби» [1, с. 22].

Через спротив і невідповідність меті й завданням радянської освіти Дальтон-план не отримав широкого застосування у вітчизняній школі, але, що важливо, він дав поштовх для наступної новації - бригадно-лабораторної форми організації навчальних занять. Під лабораторними заняттями малася на увазі будь-яка робота, яку діти роблять самі, працюючи над комплексом: читають книгу, вирішують задачу, пишуть доповідь, креслять карту. Учні об'єднувалися у бригади (6-10 чоловік) на чолі 3 бригадиром (з числа кращих учнів) і працювали за завданнями (термін виконання - від 2 тижнів до 1 місяця). Крім завдань визначалася навчальна література, контрольні питання, передбачалися вправи. Учитель консультував учнів у випадку утруднень. Оцінювалася робота всієї бригади за дальтонівською методикою, тобто за роботу бригади відповідав обраний школярами учень, а індивідуальний внесок не враховувався.

В Україні широкого розповсюдження набув такий варіант бригадно-лабораторної форми організації навчально-виховного процесу як ланкова форма, ланкова система організації праці. 
«Пояснення цьому, - зазначає В. Павловський, можна знайти, з одного боку, в тому прагненні нашої школи до колективних форм життя і праці, що становило собою ударне завдання майбутніх членів комуністичного суспільства, а $з$ другого - в спорідненості цієї форми з організаційними шуканнями диткомруху» [20, с. 53].

Ланкова організація праці, простіший варіант бригадно-лабораторної форми, спиралася також на колективні форми пізнавальної активності і самодіяльності, внутрішньому групуванні учнів не лише у лабораторії (класній кімнаті), а й у клубній, бібліотечній роботі та виробничій праці.

Ланкова організація праці була запозичена 3 дитячого руху (піонерської організації), на чому наголошували українські дослідники [19, с. 71-72]. В навчальному процесі вона спрямовувалася на навчально-пізнавальну діяльність, опанування комплексами: «це цілком зрозуміло в умовах наших шкіл, в основу яких покладена комплексна систем і трудовий метод навчання і виховання. Охопити той чи інший комплекс - це означає охопити життя у всьому його розмаїтті; сприйняття цього життя має проходити через десятки очей, вух, рук тощо. Ланки і колективна обробка цих сприймань слугують гарантією різноманіття й повноти проробки комплексу» $[19$, с. 73$]$.

Увесь процес шкільної ланкової роботи спирався на лабораторно-дослідницький, екскурсійний та активно-трудовий методи навчання дітей.

Як це відбувалося практично? Якщо група (клас) учнів складався 340 чоловік, то він поділявся на 8 ланок, що вважалося оптимальним для рухливості ланки і можливості проводити колективну роботу. Ланки будувалися за кількома принципами: за рівнем знань (ланки сильних і ланки слабких учнів); мішані ланки (сильні й слабкі учні, принцип взаємодопомоги); за інтересами дітей. Комплексні теми (або теми з окремих предметів) «пророблялися» по черзі усіма ланками. Процес роботи фіксувався у доповідях, діаграмах, схемах як іï результат. Робота кожної ланки керувалася ланковим(ою), який регулював іï діяльність, комунікував з іï учасниками, викликав їхню активність чи навпаки.

За ланкової організації праці учитель виконував роль порадника, «довідника», організатора життя і роботи дітей, мав досконало знати принципи ланкової роботи, та вмів регулювати процес [30].

Незважаючи на таку досить просту методику застосування цієї форми діяльності, вона широко обговорювалася перш за все тому, що іï сприйняло вчительство [24]. У педагогічній періодиці пропонувалися проекти програм з організації роботи за ланковою системою, висвітлюва- лися загальні умови, потрібні для праці ланками, їх організація, зміст роботи, специфіка праці поза класними кімнатами, а також облік здійсненої роботи [7].

Отже, на цьому етапі розвитку комплексування (1924-1928) в цілому були визначені принципи і підходи до такої організації навчальновиховного процесу. Комплексність спиралася на активність, самодіяльність, дослідництво, зв'язок 3 життям (середовищем), мала трудову і виробничу спрямованість через триколонкове («природа», «суспільство», «праця») розподілення матеріалу за окремими темами комплексів, застосовувалися Дальтон-план, бригадно-лабораторна та провідна форма організації - ланкова.

Але не вистачало методик, не вистачало роз'яснень, як, у який спосіб вибудовувати педагогічний процес. «Порадника», що виходив раз на рік, явно не вистачало, статті у педагогічній пресі відображали різні точки зору, а місцеві органи влади мали різний рівень компетентності і в цілому покладалися на творчість й ініціативність самих учителів. Через таку ситуацію, а також через наступальність, примус до змін, примус до відмови від традиційної системи організації педагогічного процесу, на «запаморочені голови масового вчителя» падала велика кількість новації.

В ці роки розгорнулася і серйозна дискусія щодо комплексної системи, як всеохоплюючого підходу до організації освітньо-виховного процесу, до якої долучилися й їі ідеологи, тобто керівники освіти. Головним каменем спотикання стало питання про набуття школярами формальних знань (уміннями читати, писати, рахувати, малювати, формулювати свою думку писемно й усно) та їх взаємозв'язок 3 комплексами. До полеміки долучився i Державний науковометодологічний комітет (ДНМК) Наркомосу УСРР, де Я. Чепіга виступав із спеціальною доповіддю (1924) про взаємодію системи знань і комплексів. Він висловив занепокоєння тим фактом, що велика кількість комплексних тем у «Пораднику» призвела до зменшення систематичних знань у школі, що співвідношення набутих знань до комплексів можна відобразити у форми кривої: система знань збільшується, коли зменшується комплексна робота і навпаки. Звідси педагог робив висновок: потрібно зменшити кількість комплексів (до трьох на рік), щоб збільшився час на систематичні знання. В кінцевому рахунку вчений вважав, що комплексність необхідно підпорядкувати ідеї систематичного засвоєння знань [6, с. 78].

I. Соколянський також надавав великого значення формальним знанням («репродукції засвоєного матеріалу»), але у свій спосіб. Він наполягав: «Треба визнати за величезне непорозуміння, що вважають неминучість комплексуван- 
ня тем як засіб для набування знань. Навпаки, комплексовані теми суть, мета вивчення, а знання - лише засіб, (знаряддя). На початку треба набути знань (уміння читати, писати, рахувати, формувати свої мовні вирази на письмі й усно й т. ін.) і з цими знаннями, як з засобом, підходити до студій найскладніших - комплектованих явищ життя (оточення)» [26, с. 14]. Більшість педагогів також були упевнені, що «коли школа не дає знань, то там немає й комплексової роботи, бо остання без знань немислима», що «необхідно установити мінімум знань» для кожного класу, що лише одна організація педагогічного процесу не гарантує успіх шкільної роботи - «мало організувати, треба зуміти ii виконати, потрібно озброїтися доскональною методикою, якої, мусимо сказати, зараз ще немає» [6, с. 79-80]. Другою значною проблемою стало питання зв'язку комплексних програм і політичних тем, внесення яких «було трохи штучним», бо вони «порушують єдність педагогічного процесу». При цьому наводився як приклад комплекс «Жовтнева революція», де в колонці «природа» зазначалося: колір листя, шум екіпажу. Щоб усунути цю штучність пропонувалося проводити окремі «політдні», як великі кількаденні комплекси (Жовтнева революція, смерть Леніна, криваві події, Перше травня), або як одноденні комплекси - свята або ж розподілити політичні події за іншими (переважно виробничими) темами [15, с. 34].

Політичні комплекси, які сприймалися педагогами в 1925-1926 роках як невмотивовані і штучні, досить швидко посіли там чільне місце, стали визначальними, разом із виробничою тематикою.

Наступною і більш відчутною педагогічною проблемою, як відзначали українські педагоги, став той факт, що учителів не вистачало і один і той же учитель працював 3 двома - трьома групами (класами) одночасно. І це були не поодинокі випадки - «таких шкіл переважна більшість» $[15$, с. 35], і вчителі змушені були одночасно застосовувати різні форми роботи (за принципами організації роботи малокомплектної школи).

Проблемним питанням було і забезпечення школи навчальними книгами, бо «ті книжки, які є на ринкові та в школі, не придатні для праці за комплексовою системою» [12, с. 52]. Хоча ця проблема поступово усувалася, i багато хто 3 учителів і науковців інтенсивно працювали над створенням відповідних підручників. Особливо плідним у цьому відношенні був Я. Чепіга, який у своїх книжечках «Буквар для малечі», «Арифметика», «Веселка. Перша читанка після букваря», «Рідна мова» тощо будував матеріал за комплексним підходом.

Але, мабуть, найбільші проблеми щодо втілення комплексного підходу у навчальному процесі накопичувалися у старшому концентрі семирічної школи (5-7 кл.), бо на практиці виявлялося, що «сільська школа майже не знає комплексів у старших групах. Трапляються і в місті школи, де ще панує предметова система. Навіть серед досвідних установ помічається таке явище» $[12$, c. 55].

В старшому концентрі, як правило, проводилася лекційна (предметна) форма навчання, але також застосовувалися «епізодичні комплекси, які розглядалися як підготовка до комплексної системи на тлі предметової системи» («Село», «Біостанція юних натуралістів», «Південна Америка»). Значно менше було шкіл, де повністю застосовувалася комплексна система, I. Лень називає, наприклад, лише 3 такі школи [12, с. 55]. I серед тієї невеликої кількості шкіл, які застосовували комплексну систему у старшому концентрі, налічувалися ті, що працювали за російськими схемами ГУСу (їх було більше), i ті, що працювали за «українським типом комплексу». Програми ГУСу залишали в другому концентрі предметне викладання, об'єднували окремі предмети лише на початку викладання й у самому кінщі, пропонуючи загальні теми. В школах, що працювали за «Порадниками», у старшому концентрі матеріал подавався за єдиним комплексом із поділом матеріалу на три колонки «природа», «праця», «суспільство» або із зазначенням комплексу в одній колонщі.

В теорії передбачалося, що «український тип комплексу вже не лишає в школі предметової системи. Тут ми, дійсно, маємо вивчення не дисципліни, а життьових явищ, трудової діяльности людей. I не від окремих дисциплін ми йдемо до життьових тем, а навпаки, від цих тем ми починаємо i, орієнтуючись на них, розв'язуємо питання: як організувати працю, як розподілити іï між педагогами, чи потрібні тут окремі дисципліни й т. ін.» [12, с. 58].

До питань організації навчального процесу у старшому концентрі (5-7 кл.) додавалися і питання методів і способів вивчення трудової діяльності людини за відповідними колонками комплексів, і сама організація суспільно корисної праці, залежно від теми комплексу. Але найболючіша 3 них була проблема об'єму і місця формальних знань (математичних рівнянь, геометричних теорем, хімічних формул, граматичних правил) та формування умінь і навичок їх застосування. Ці останні намагалися вирішувати поза комплексом, проводячи додаткові заняття «міжкомплексові простори», або під час комплексу на «некомплексовому матеріалі».

Усі ці питання, що так гостро стояли, але так і не були вирішені упродовж усього періоду 1920-х років, проходили в умовах певного хаосу, неузгодженості, спорадичної ініціативності, яка не завжди спиралася на справжні знання, компе- 
тентність, професіоналізм. Ці роки можна назвати як «педагогічна робінзонада», коли освіта опинилася на «невідомому острові», й гостроактуальні питання вирішувалися спонтанно, інтуїтивно, методом проб і помилок.

В ці роки нова методологія, нові форми й методи навчання вимагали й нових підходів до оцінювання, обліку результатів навчальновиховного процесу, як його перебігу, так і досягнень. Стара система, що застосовувалась у дореволюційній школі або в освіті періоду української державності, - оцінки, премії, заохочення, критикувалася як непридатна до радянської системи. Отже, потрібен був новий облік праці учнів, нові критерії, нові вимірники.

I тут ситуація, на наш погляд, була кращою, ніж у розробці комплексів, тому що в ті роки інтенсивно розвивалися психотехніка та педологія, які спиралися на різного роду вимірники, тести. Вони були тісно пов'язані 3 комплексною системою, бо лежали в ії основі, виходили з ідеї всебічного вивчення дитини, комплексного підходу до цього процесу та міждисциплінарного синтезу.

На жаль, вивчення результатів діяльності дітей, і в першу чергу навчальної, яка здійснювалася в 1920-ті роки, майже не представлено в сучасному історико-педагогічному просторі, крім статті Л. Ковальчук [10], а література щодо розвитку психотехніки обмежена, можемо послатися на власну статтю, в якій серед іншого йдеться й про психотехнічні методи вимірювання [29].

Що ж стосується вимірників у педології, то «існує багато педологічних методів (біографічний метод, природний експеримент, психоаналіз, метод вивчення продуктів дитячої творчості, анкетний метод, тести, лабораторний психологічний експеримент, метод кореляції, порівняльний метод» [31, с. 18].

До цього напряму роботи, тобто до вимірювання і обліку, педагоги підійшли всебічно: спираючись на рефлексологічні, педологічні та психотехнічні підвалини, вони співставляли працю дитини і вимірювали результати ії діяльності не лише якістю виконаної роботи, а й показували ії залежність від середовища, у якому вона знаходиться, з іï фізичним станом, анатомічною будовою, спадковістю тощо.

Розпочинався процес з вивчення фізичного стану кожного учня для того, щоб знати і кожну дитину, і склад групи чи колективу. Надалі увага зосереджувалася власне на облікуреєстрації стану та обліку наслідків, результатів роботи. Ось такий вигляд мав щоденник, що підсумовував працю дітей при опрацюванні певного комплексу ${ }^{3}$.

\footnotetext{
${ }^{3}$ Схема подається за: Лозинський С. 3 практики комплексної роботи в школі. Харків: Книгоспілка, 1927. С. 50.
}

Таблиия 3.

Форма ч. 1

\section{За комплексною системою}

\begin{tabular}{|c|c|c|c|c|}
\hline \multirow{2}{*}{\multicolumn{2}{|c|}{\begin{tabular}{c|c} 
Груповий & \\
\cline { 2 - 2 } щоденник & \\
сторінка. День. \\
Місяць, число. \\
Спис. дітей. \\
Тема комплексу
\end{tabular}}} & \multicolumn{3}{|c|}{ Відсутні } \\
\hline & & Прізвище & \multicolumn{2}{|c|}{ Причина } \\
\hline \multirow[t]{2}{*}{$\begin{array}{c}\text { Предмет } \\
\text { праці } \\
\end{array}$} & $\begin{array}{c}\text { Тема й } \\
\text { форма праці }\end{array}$ & Продукція... ${ }^{4}$ & Активність... 5 & Примітка \\
\hline & \multicolumn{4}{|c|}{$\begin{array}{l}\text { 1. } \text { Моменти, що оживили працю групи } \\
\text { 2. } \\
\text { Моменти, що розладнали працю групи }\end{array}$} \\
\hline
\end{tabular}

Форма ч. 2

\begin{tabular}{|c|c|c|}
\hline \multirow{2}{*}{$\begin{array}{c}\text { Шкільний журнал } \\
\text { День. Місяць, число. } \\
\text { Черговий у школі педагог } \\
\text { Черговий у школі учень }\end{array}$} & \multicolumn{2}{|c|}{ Відсутні } \\
\hline & Кількість & Причина \\
\hline \multicolumn{3}{|l|}{ Загальний характер дня............ } \\
\hline \multicolumn{3}{|l|}{ Настрій дітей........................ } \\
\hline \multicolumn{3}{|l|}{ Діти під час перерв.................. } \\
\hline \multicolumn{3}{|l|}{ Діти під час сніданку................... } \\
\hline \multicolumn{3}{|l|}{$\begin{array}{l}\text { Праця органів } \\
\text { «Молодих Піонерів»................... }\end{array}$} \\
\hline \multicolumn{3}{|l|}{ Праця гуртків......................... } \\
\hline \multicolumn{3}{|l|}{ Органи самоврядування............. } \\
\hline \multicolumn{3}{|l|}{ Моменти, що оживили день........ } \\
\hline \multicolumn{3}{|l|}{ 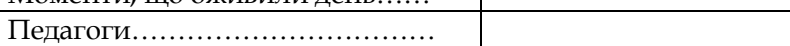 } \\
\hline 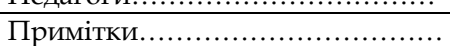 & & \\
\hline
\end{tabular}

За допомогою таких та багатьох інших обіжників обчислювалися, «які зміни спостерігалися в соціальних реакціях дітей залежно від установлення тих чи інших певних форм зв'язку між дитячим колективом та даним виробництвом чи суспільною організацією; або - як і до якої міри вплинули на дітей зміни в матеріальних умовах життя школи; або - наскільки збільшилася продуктивність праці в царині трудових процесів після того, як пристосовано ті чи інші методи навчання. Одним словом, цей облік загадує встановити залежність між педагогічними стимулами, що виходять з окремих частин педагогічного процесу чи від нього в цілому, та реакціями дітей - цебто встановити справжній облік наслідків педагогічної праці за даний протяг часу; i лише такий облік визначить дійсну успішність праці, іiї продукцію» [14, с. 46].

Для організації такої роботи кабінети соціальної педагогіки, які, власне, і проводили їі, використовували тестування, яке, як ми знаємо, було провідною методологією педагогічної теорії і практики. 3 цією метою адаптувалися тести, які були розроблені європейськими й американсь-

\footnotetext{
4 Продукція - це наслідки праці в розумінні проробленого матеріалу - що виконано.

5 Активність - відношення до праці, міра інтенсивності.
} 
кими вченими, створювалися власні, а також широко застосовувалися різного роду картки, схеми, діаграми, які отримали в ті роки широке розповсюдження. Важливими формами обліку були також облікові картки, щоденники, протоколи загальних зборів, журнали.

Педагоги ж, метою яких було виявлення причин залежностей і наслідків наявних досягнень учнів, використовували крім вимірників, класні журнали, систематичне спостереження за роботою учнів, оцінку результатів праці. Облік праці відігравав також велику роль у формуванні суспільної думки про школу, освіту, особливо у найближчому середовищі, серед батьків учнів того мікрорайону, де знаходилася установа.

В кінці 1928 р. в Радянському Союзі був затверджений перший п'ятирічний план (1928/ 1929-1932 рр.), який поклав початок плановому господарюванню, вже повним ходом йшла колективізація, був взятий курс на індустріалізацію і реконструкцію промисловості. Розпочалася реконструктивна доба, яка відкривала період ідей та відповідних дій про наростання класової боротьби в державі, більш гострого протистояння 3 капіталізмом, виявлення і боротьбу з внутрішніми ворогами, а також перевиховання («перековки») значної кількості населення, критики і самокритики, впровадження звульгаризованого марксизму і ленінізму в усі без винятку сфери життя і діяльності радянської держави.

У січні 1930 р. Державний науковометодологічний комітет (ДНМК), який з 1925 року керував усією науково-методичною роботою в УСРР, затвердив новий проект комплексних програм, відкоригований постановами липневого пленуму ЦК ВКП (б) 1929 р., що вимагали «чіткої ідеологічної лінії щодо соціалістичного виховання й перевиховання мас». Комплексне навчання за такими настановами підлягало значному перегляду. До комплексів вносилися такі теми як колективізація, індустріалізація, культурна революція, загострення класової боротьби, що незабаром стали провідними ідеями комплексів.

Отже, комплексність почала розглядатися лише у політичній площині - як розкриття проблем «класової боротьби» та соціалістичного будівництва й участі у цьому процесі дітей. Серед чинників, що впливали на розвиток дитини, на перше місце було висунуто оточення: «Для епохи соціалістичної реконструкції велика соціалістична промисловість і колективізоване сільське господарство стає за те оточення, що становить собою економічну й громадську базу боротьби і виховання... Партія, комсомол, дитрух, ради, профспілки, кооперація, виробництва та колгоспи - справжні фактори пролетарського комуністичного оточення, вони ж і мають стати за основу педагогічного процесу - комуністичного ви- ховання» [11, с. 5]. Під цим кутом зору переглядався зміст освіти, тобто комплекси.

3 метою ще більшого унормування ідей комплексності, і великою мірою політизації та ідеологізації освіти взагалі і школи зокрема, ДНМК визначив: «педагогічний процес треба розуміти як процес організації обумовлених форм класової поведінки людського колективу в цілому та окремої особи через колектив. За доби соціалістичної реконструкції цей процес означає ще вище підносити прапор класової боротьби для соціалістичного наступу та знищення капіталістичних елементів» [11, с. 5].

В тезах ДНМК зазначається, що під комплексністю потрібно розуміти: конкретну і актуальну проблему соціалістичного будівництва соціалістичної реконструкції; конкретну життєву складність явищ, вивчати ії через трудову діяльність людей, впливати на об'єкти, що вивчаються, не лише теоретично, а й практично; поєднувати у своїй практичній діяльності різні галузі знань, що допоможе краще й ефективніше перетворювати діяльність [11, с. 5-10].

Ці директивні тези, на відміну від попередніх, підходять до комплексування не крізь призму трудової діяльності, виробничої праці, як було раніше, а виключно крізь призму ідеології та політехнічного підходу, якому дотепер в Україні не приділялася значна увага. Підкреслювалося, що комплексна система стає ще більш актуальною в політехнічній школі, яка має, за ідеями К. Маркса і Ф. Енгельса, такі ознаки: безпосередня участь дітей у виробничій продуктивній праці, тобто у процесах соціалістичної реконструкціï; обізнаність із загальними науковими принципами всіх виробничих процесів та їх практичним застосуванням; поєднання виробничої праці iз фізичним вихованням та розумовим (інтелектуальним) розвитком. Все це закладено в комплексній системі, яка і відповідає процесу комуністичного виховання [11, с. 9].

В цьому ж документі зазначалося, що «метода проектів в частині здійснення комплексної системи є найраціональніше доповнення удосконалення комплексності... Окремі завдання (проекти) є частина цілого комплексу, але раціональний розподіл праці не тільки не заперечує принципу комплексності, а ще збільшує рентабельність та ефективність комплексної системи, тому систему завдань (проектів), як спосіб реалізації комплексування, треба обов' язково включати в педагогічний процес» [11, с. 9].

Метод проектів, який рекомендує ДНМК у аналізованому документі, не отримав достатнього розповсюдження на попередніх етапах застосовування комплексності в Україні, проте він застосовувався в РСРФР і звідти прийшов до нас на самому початку 1930-х років. 
В радянських умовах кінця 1920-х років той зміст, що не входив у комплекси («природа», «суспільство», «праця»), але знаходився в центрі парадигми трудової школи - краєзнавча, дослідницька робота, особливо соціально-ідеологічна тематика, почав розглядатися як проектна методика, а вся система отримала назву «комплекснопроектної». М. Богуславський зазначає, що матеріали, які виходили з Інституту методів шкільної роботи (Москва), де працювали радянські теоретики педагогіки (В. Шульгін, М. Крупеніна, Ф. Трахтенберг) гіпертрофовано підкреслювали класову, соціологічну спрямованість методик навчання, при цьому наголос переносився 3 навчання на виховання школярів. В цих умовах від проектного методу вимагалося в першу чергу забезпечення «марксистсько-ленінського світогляду», а також органічне включення школярів у суспільно корисну працю виробничого спрямування, прищеплення єдиного всезагального способу мислення i пізнання - діалектичного. «В результаті такого підходу, - зазначає вчений, в якості єдиного і унікального методу, починаючи 31928 р., визнавався «метод проектів», який тлумачився як «соціально-трудовий метод» $[2$, c. 230].

Замість дослідницького методу усталюється виробничо-дослідницький, вводиться виробниче краєзнавство і трудові екскурсії як складові політехнізму, впроваджувалося «соцзмагання» як вимірник результативності навчання чи виховання. Пропонувалося підходити до навчальновиховного процесу як до частини виробництва або сільського господарства, і школа мала перепрофілюватися на школу-завод, школу-фабрику, а замість поділу учнів на групи пропонувався їхній поділ на бригади та ланки [27]. Через такий підхід до побудови освіти сама школа як окремий освітній заклад була під запитанням.

Ця виробничо-трудова точка зору почала посідати на початок 30-х років панівне місце, вона була агресивно-наступальна і оперувала переважно політичними гаслами, марксистською риторикою, підпорядковувала інші підходи - соціально-педагогічний (А. Пінкевич) і культурноантропологічний (М. Рубінштейн).

I хоча в Україні таких ультрареволюціонерів не було, все ж виробничий ухил через комплексно-проектну систему отримав свій розвиток. Наряду з комплексами в школах все частіше виконувалися такі проекти, як «Допоможемо ліквідувати неграмотність», «Допоможемо нашому заводу-шефу виконати промфінплан», «Виростимо нову породу свиней», «Допомога в кампанії перевиборів у ради» тощо. Почали з'являтися, особливо у промислових регіонах України, такі утворення як «школа-цех заводу». Школи укладали 3 великими і малими виробництвами дого- вори, за якими зобов' язувалися «переробити свій учбовий план в напрямі більшого задоволення думок заводу, скоротити навантаження учнів по школі, підпорядкувати весь свій педпроцес основній установі - найбільше усвідомити й вивчити виробничий процес заводу, допомогти йому у виконанні промфінпляну тощо» [21, с. 56].

I хоча, судячи із директивного документу тез ДНМК, який ми аналізували, українське керівництво, слідом за Росією, чітко взяло курс на проектний метод, втілити цю ідею не вдалося. Очільники радянської держави бачили, що ідеї «відмирання школи», тобто заміни ії на школуфабрику, школу-завод вже наближаються до абсурду, що у педагогічній науці наростає відчутна криза, яка мала назву «суперечливі проблеми марксистської педагогіки», а вони були суперечливими на всьому проблемному полі: i щодо предмета марксистської педагогіки, і щодо організації педагогічного процесу, розуміння педагогіки середовища, політехнічної освіти, сутності виховання тощо. Педагоги весь час дискутували, пропонували щораз інші варіанти організації педагогічного процесу, що все більше розходилося із намірами партії, перед якою постало питання соціалістичної реконструкції, виконання першого п'ятирічного плану, індустріалізації, поглиблення колективізації, а для вирішення цих завдань потрібні були кваліфіковані і професійні кадри. I не чекаючи результатів пошуку виходів із кризи, партія взяла все у свої руки, i серією постанов 1931-1937 рр. припинила будьякі новації. Постанови в організаційному плані повернули освітній простір до класичних (дореволюційних) форм, а в змістовому - наситили матеріалістичним, науковим матеріалом усі програми навчальних предметів, з суто радянською ідеологічною, партійною надбудовою.

В одній з перших постанов ЦК ВКП (б) від 5 вересня 1931 р. «Про початкову і середню школу» теорія «відмирання школи» була названа «антиленінською», а наміри покласти в основу всієї шкільної роботи «так званий «метод проектів» класифікувалися як «руйнування школи» [18].

Так закінчився період шукань і випробувань у педагогічній науці та в організації і діяльності шкільної освіти. Директивно припинили своє існування такі науки як рефлексологія, психотехніка, педологія, які виступали методологічними i теоретичними засадами в питаннях організації і функціонування всього освітньовиховного процесу. Зі школи зникло комплексне навчання і комплексування в усіх його проявах i виявах, відбулося повернення до традиційних, форм і методів викладання, але з повною заміною змісту освіти. Цю заміну - як суто радянську підготував період застосування комплексності в початковій і середній школі. В подальшому цей 
зміст розподілявся не за комплексами, а за предметами.

Таке грубе втручання, інтервенції в галузь освіти, офіційна заборона наук про освіту, директивна заборона дослідницької, експериментальної роботи зробили найгірше - припинили еволюційний розвиток підходів до організації і форм і методів діяльності загальноосвітньої школи як найважливішої суспільної інституції; не лише викреслили творців нової школи з істоpiї розвитку науки, а й навісили на них ярлики ворогів, «шпигунів» і зрадників, які «плазують» перед «буржуазною» наукою.

Підсумовуючи наш аналіз, зазначимо, що в основі комплексів і комплексування лежала ціла система, що складалася 3 урахування природи дитини, іii інтересів та потреб (спадковість, вікові i національні психофізіологічні особливості, найближче оточення); складної системи залежностей між розвитком школярів та знаннями, які вони одержують; наголошення на важливості відбору засобів опанування знаннями; встановлення багаторівневих зв'язків і залежностей між процесами набуття знань та життям (оточенням); побудовою освіти в такий спосіб, щоб ії результатом став розвиток дитини, колективу; обгрунтування особливостей місця та ролі учителя в процесі навчання і багато іншого.

I хоча на початковому етапі застосування комплексного підходу дитина розглядалася 3 педологічних позицій, тобто в центрі системи знаходився ії розвиток, досить швидко на передній план висунулися засоби опанування знаннями, оволодіння певними навичками (рефлексологія). Знання, а точніше «вузли знань», одержані в школі, були пов'язані 3 повсякденним життям дитини, іï оточенням, мали носити дієвий, перетворювальний характер.

За спрямованістю педагогічного процесу комплексна системи була спочатку зорієнтована на індивід, але досить швидко переорієнтувалася на колектив, хоча характер взаємостосунків між його учасниками залишався педоцентристським, учитель відігравав допоміжну роль.

1920-м рокам ми завдячуємо появі авторських концепцій комплексності таких вчених як Г. Іваниця, О. Музиченко, І. Соколянський, Я. Чепіга. Вони відрізнялись одна від одної не лише розумінням того, що ж являв собою комплекс, а й гносеологічно - виходили з різних методологічних позицій. Ці концепції відіграли значну роль в розвитку вітчизняних педагогічних ідей. Вони являли собою не лише теоретичні побудови, а були втілені в підручники, в практику роботи навчальних закладів.

Короткочасність і швидкоминучість комплексів $i$ комплексного підходу слід віднести до зміни освітньої парадигми і почасти до їх недосконалості, а і цих останніх було досить багато. До головних відносяться:

- поступове висунення радянського варіанту марксизму як обов'язкової методологічної основи розвитку педагогічної науки і світоглядної діяльності школи;

- директивність, обов'язковість для всіх без винятку шкіл і вчителів, що для новацій будь-якого гатунку несе в собі елементи невдачі;

- закладена майже від самого початку невідповідність між формами і методами (активність, ініціатива, розвиток, пошук, самостійність, саморозвиток) й змістом (марксистські догми, вузька класовість, політизація, невідповідність дитячим запитам і інтересам);

- спочатку недостатність, а пізніше перенасичення різними методичними порадами щодо розробки комплексів;

- обов'язкова присутність політикоідеологічного змісту;

- нехтування формальними знаннями, кореляції між розвитковими й систематичними знаннями, нерозробленість i нерозв' язаність цієї проблеми;

- недостатнє фінансово-матеріальне забезпечення впровадження комплексної системи.

Але попри все 1920-ті роки, такі невеликі за перебігом часу, були максимально насичені сміливими педагогічними пошуками, різноманітною практикою. Вони збагатили дослідницьке поле історико-педагогічної науки плідними ідеями, виступили й ще досить довго будуть виступати джерелом, майже невичерпним, 3 якого будуть живитися не лише дослідники - історики, історики педагогіки, а й педагоги-практики у сьогоднішніх пошуках відповідей на питання, які ставить освіта на початку XXI століття.

\section{СПИСОК ВИКОРИСТАНИХ ДЖЕРЕЛ}

1. Ананьїн С. До питання про знесення лекційної системи. Радянська освіта. 1924. Ч. 3-4 (березень-квітень). С. 20-25.

2. Богуславский М. История отечественной педагогики (первая треть XX века). Томск: Изд-во НТЛ, 2005. 312 с.

3. Большакова I. О. Комплексне навчання у 20х pp. XX ст. як джерело розвитку між предметної інтеграції змісту навчання другої половини XX ст. Збірник наукових працъ. 2015. Вип. 18(1-2015). С. 36-41.

4. Выготский Л. С. К вопросу о плане научноисследовательской работы по педологи национальных меньшинств. Педология. 1929. № 3. С. 367-377.

5. Выготский Л. С. Педология и психотехника. 
Культурно-историческая психология. 2010. № 2. C. 105-120.

6. Гарбуз Т. Етапи в розвиткові комплексових програмів. Путь просвещзения. 1925. № 9(29). С. $74-81$.

7. Дурдуківський В. Проект програми для дослідної роботи у справі вивчення ланкової системи праці в трудовій школі. Радянська ocbima. 1927. № 1. С. 36-42.

8. Единый учебно-воспитательный план соцвоса. Руководство по соииальному воспитанию. 4-е изд., перераб. Харьков. Государственное изд-во Украины, 1924. С. 133-294.

9. Іваниця Г. Комплексне навчання. Радянська осbima. 1924. Ч. 1-2 (січень-лютий). С. 118-121.

10. Ковальчук Л. І. Проблеми результативності навчального процесу в контексті педологічної науки (Перша третина XX століття). Молодий вчений. 2016. № 5(32) травень. C. 335-340.

11. Комплексна система за доби соціалістичноі реконструкції. Тези Державного науковометодологічного комітету. Харків: Раб. просвещения, 1930. 16 с.

12. Лень I. До питання про комплексовість у старшому концентрі семирічки. Шлях освіmu. 1926. № 10. С. 51-67.

13. Липинський В.В.Становлення і розвиток нової системи освіти в УРСР у 20-х роки. Донецьк, 2000. 248 с.

14. Лозинський С. 3 практики комплексної роботи в школі. Харків: Книгоспілка, 1927. 105 c.

15. Мостовий А. Болючі моменти комплексової системи. Радянська освіта. 1925. № 2. С. 32-35.

16. Мостовий П. Концепції комплексовости на Україні. Комуністична освіта. 1931. № 4 . C. 105-131.

17. Нариси історії українського шкільництва (1905-1933) / за ред. О. В. Сухомлинської. Київ, 1996. 304 с.

18. О начальной и средней школе». Постановление ЦК ВКП (б) от 5 сентября 1931 г. Директивы ВКП (б) и постановления советского правительства о народном образовании за 19171947 г2. Москва - Ленинград: Изд-во АПН РСФСР, 1947. С. 151-159.

19. Павловский В. К вопросу о звеньевой организации работы в школах Соцвоса. Путь просвещения / Шиях освіти. 1925. № 5/6. С. 71-80.

20. Павловський В. Програмово-дидактичні шукання Жовтня в українській педагогічній літературі. Радянська освіта. 1927. № 11. С. 46-56.

21. Павловський В. Основні етапи розвитку політехнічної школи на Україні. Комуністична ocbima. 1932. № 10. С. 44-61.

22. Пистрак М. М. Педагогика. Москва: Госучпедгиз, 1934. 420 с.
23. Практика Дальтон-плана в советских шко-

24. Практика ланкової праці в трудовій школі / за ред. О. С. Залужного. Харків: ДВУ, 1929. 153 c.

25. Соколянский. Социальные и биологические моменты в детском движении. Путь просъещзения. 1924. № 6(26). С. 206-208.

26. Соколянський I. Організація педагогічного процесу за комплексовою системою, методика і методична техніка. Радянська освіта. 1926. № 1. С. 11-16.

27. Спорные проблемы марксистской педагогики / под ред. А. З. Иоанисиани. Москва: Раб. просвещения, 1930. 411 с. URL: www.detskiysad. $\mathrm{ru} / \mathrm{ped} /$ marksist.html/

28. Сухомлинська О.В.Комплексне навчання в школах України. Нариси з історії украӥнського шкільництва (1905-1933): навч. посіб. Київ: Заповіт, 1996. С. 153-207.

29. Сухомлинська О. В. Психотехніка - втрачений напрям радянської педагогічної науки і практики. Історико-педагогічний альманах. 2012. Вип. 2. С. 2-12.

30. Таран В. Ланки в комплексовій системі. Радянська освіта. 1925. Ч. 6-7. С. 36-43.

31. Тарасевич Н. Педология и ее значение в современном педагогическом строительстве. Путь просвещзения. 1923. № 4. С. 1-22.

32. Філімонова Т. В. Дитячі містечка - новаторський проект ранньорадянського періоду. Нариси 3 історії розвитку новаторських навчально-виховних закладів в Україні (кінець ХІХ - ХХ сm.). Луганськ: ЛНУ імені Тараса Шевченка, 2010. С. 190-248.

33. Чепіга Я. Практична трудова педагогіка. Київ, Харків, 1924. 120 с.

34. Эткинд А. М. Эрос невозможного. История психоанализа $b$ России. Санкт-Петербург:

35. Медуза, 1993. URL: https://www.psyoffice. ru/2529-jetkind-aleksandr.-jeros-nevozmozhno go.-istorija.html

36. Янченко Т. Педологія в Україні та зарубіжжі: теорія і практика: монографія. Чернігов: Десна Поліграф, 2016. 448 с.

\section{REFERENCES}

1. Ananin, S. (1924). Do pytannia pro znesennia lektsiinoi systemy. Radianska osvita, Ch. 3-4 (berezen-kviten), 20-25 [in Ukrainian].

2. Boguslavskij, M. (2005). Istorija otechestvennoj pedagogiki (pervaja tret' HH veka). Tomsk: Izdvo NTL [in Russian].

3. Bolshakova, I. O. (2015). Kompleksne navchannia u 20-x rr. XX st. yak dzherelo rozvytku mizh predmetnoi intehratsii zmistu navchannia druhoi polovyny KhKh st. Zbirnyk naukovykh prats, Issue 18(1-2015), 36-41 [in Ukrainian]. 
4. Vygotskij, L.S. (1929). K voprosu o plane nauchno-issledovatel'skoj raboty po pedologi nacional'nyh men'shinstv. Pedologija, 3, 367-377 [in Russian].

5. Vygotskij, L. S. (2010). Pedologija i psihotehnika. Kul'turno-istoricheskaja psihologija, 2, 105-120 [in Russian].

6. Harbuz, T. (1925). Etapy v rozvytkovi kompleksovykh prohramiv. Put prosveshchenyia, 9(29), 74-81 [in Ukrainian].

7. Durdukivskyi, V. (1927). Proekt prohramy dlia doslidnoi roboty u spravi vyvchennia lankovoi systemy pratsi v trudovii shkoli. Radianska osvita, 1, 36-42 [in Ukrainian].

8. Edinyj uchebno-vospitatel'nyj plan socvosa. (1924). Rukovodstvo po social'nomu vospitaniju. Har'kov: Gosudarstvennoe izd-vo Ukrainy, 133-294 [in Russian].

9. Ivanytsia, H. (1924). Kompleksne navchannia. Radianska osvita. Ch. 1-2 (sichen-liutyi), 118-121 [in Ukrainian].

10. Kovalchuk, L. I. (2016). Problemy rezultatyvnosti navchalnoho protsesu $\mathrm{v}$ konteksti pedolohichnoi nauky (Persha tretyna XX stolittia). Molodyi vchenyi, 5(32) traven, 335-340 [in Ukrainian].

11. Kompleksna systema za doby sotsialistychnoi rekonstruktsii. (1930). Tezy Derzhavnoho naukovo-metodolohichnoho komitetu. Kharkiv: Rab. prosveshchenyia [in Ukrainian].

12. Len, I. (1926). Do pytannia pro kompleksovist $\mathrm{u}$ starshomu kontsentri semyrichky. Shliakh osvity, 10, 51-67 [in Ukrainian].

13. Lypynskyi, V. V. (2000). Stanovlennia i rozvytok novoi systemy osvity v URSR u 20 roky. Donetsk [in Ukrainian].

14. Lozynskyi, S. (1927). Z praktyky kompleksnoi roboty v shkoli. Kharkiv: Knyhospilka [in Ukrainian].

15. Mostovyi, A. (1925). Boliuchi momenty kompleksovoi systemy. Radianska osvita, 2, 32-35 [in Ukrainian].

16. Mostovyi, P. (1931). Kontseptsii kompleksovosty na Ukraini. Komunistychna osvita, 4, 105-131 [in Ukrainian].

17. Narysy istorii ukrainskoho shkilnytstva (19051933). (1996). O. V. Sukhomlynskoi (Ed.). Kyiv [in Ukrainian].

18. O nachal'noj i srednej shkole. Postanovlenie CK VKP (b) ot 5 sentjabrja 1931 g. (1947). Direktivy VKP (b) i postanovlenija sovetskogo pravitel'stva o narodnom obrazovanii za 1917-1947 gg. Moskva Leningrad: Izd-vo APN RSFSR, 151-159 [in Russian].

19. Pavlovskij, V. (1925). K voprosu o zven'evoj organizacii raboty $\mathrm{v}$ shkolah Socvosa. Put'
prosveshhenija/Shljah osviti, 5/6, 71-80 [in Russian].

20. Pavlovskyi, V. (1927). Prohramovo-dydaktychni shukannia Zhovtnia $\mathrm{v}$ ukrainskii pedahohichnii literaturi. Radianska osvita, 11, 46-56 [in Ukrainian].

21. Pavlovskyi, V. (1932). Osnovni etapy rozvytku politekhnichnoi shkoly na Ukraini. Komunistychna osvita, 10, 44-61 [in Ukrainian].

22. Pistrak, M. M. (1934). Pedagogika. Moskva: Gosuchpedgiz [in Russian].

23. Praktika Dal'ton-plana v sovetskih shkolah. (1926). Leningrad: Gos. izd-vo, 10-30 [in Russian].

24. Praktyka lankovoi pratsi $\mathrm{v}$ trudovii shkoli. (1929). O. S. Zaluzhnoho (Ed.). Kharkiv: DVU [in Ukrainian].

25. Sokoljanskij. (1924). Social'nye i biologicheskie momenty $\mathrm{v}$ detskom dvizhenii. Put' prosveshhenija, 6(26), 206-208 [in Russian].

26. Sokolianskyi, I. (1926). Orhanizatsiia pedahohichnoho protsesu za kompleksovoiu systemoiu, metodyka i metodychna tekhnika. Radianska osvita, 1, 11-16 [in Ukrainian].

27. Spornye problemy marksistskoj pedagogiki. (1930). A. Z. Ioanisiani (Ed.). Moskva: Rab. Prosveshhenija. URL: www.detskiysad.ru/ ped/marksist.html/ [in Russian].

28. Sukhomlynska, O. V. (1996). Kompleksne navchannia v shkolakh Ukrainy. Narysy z istorii ukrainskoho shkilnytstva (1905-1933). Kyiv: Zapovit, 153-207 [in Ukrainian].

29. Sukhomlynska, O. V. (2012). Psykhotekhnika vtrachenyi napriam radianskoi pedahohichnoi nauky i praktyky. Istoryko-pedahohichnyi almanakh, Issue 2, 2-12 [in Ukrainian].

30. Taran, V. (1925). Lanky v kompleksovii systemi. Radianska osvita, 6-7, 36-43 [in Ukrainian].

31. Tarasevich, N. (1923). Pedologija i ee znachenie v sovremennom pedagogicheskom stroitel'stve. Put' prosveshhenija, 4, 1-22 [in Russian].

32. Filimonova, T. V. (2010). Dytiachi mistechka novatorskyi proekt rannoradianskoho periodu. Narysy z istorii rozvytku novatorskykh navchalnovykhovnykh zakladiv v Ukraini (kinets XIX XX st.). Luhansk: LNU imeni Tarasa Shevchenka, 190-248 [in Ukrainian].

33. Chepiha, Ya. (1924). Praktychna trudova pedahohika. Kyiv, Kharkiv [in Ukrainian].

34. Jetkind, A. M. (1993). Jeros nevozmozhnogo. Istorija psihoanaliza $v$ Rossii. Sankt-Peterburg: Meduza, URL: https://www.psyoffice.ru/ 2529-jetkind-aleksandr.-jeros-nevozmozhnogo.istorija.html [in Russian].

35. Yanchenko, T. (2016). Pedolohiia v Ukraini ta zarubizhzhi: teoriia i praktyka. Chernihov: Desna Polihraf [in Ukrainian]. 